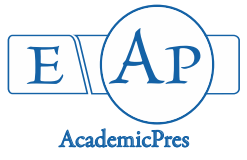

Oke FM et al. (2020)

Notulae Scientia Biologicae 12(4):920-928

DOI: $10.15835 / 12410814$

Research Article

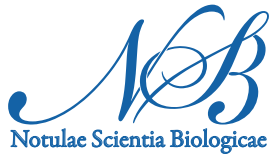

\title{
Bioremediation of diesel polluted soils with Eichhornia crassipes (water hyacinth)
}

\author{
Felix M. OKE ${ }^{1}$, Charlotte C. NDIRIBE ${ }^{1}$, Saheed I. MUSA ${ }^{2 *}$ \\ ${ }^{1}$ University of Lagos, Faculty of Science, Department of Cell Biology and Genetics, Lagos State, \\ Nigeria;Talk2leodgreat@gmail.com;Charlotteblue2001@yahoo.com \\ ${ }^{2}$ Admiralty University of Nigeria, Faculty of Science, Department of Biological Sciences, Delta State, \\ Nigeria; Musa-biology@adun.edu.ng ("corresponding author)
}

\begin{abstract}
Diesel oil contamination is a growing environmental concern in most crude oil processing regions of the world. This study assessed the efficacy of both fresh and powdered Eichhornia crassipes (water hyacinth) as potential biostimulants in the remediation of diesel oil contaminated soils using three test concentrations ( 50 $\mathrm{g}, 100 \mathrm{~g}$ and $150 \mathrm{~g}$ ) and a control $(0 \mathrm{~g})$. The remediation process was monitored by assaying the total organic carbon (TOC), total petroleum hydrocarbon (TPH), and soil $\mathrm{pH}$ before and after amendment with the fresh and powdered E. crassipes for 90 days. The result showed increase in soil $\mathrm{pH}$, TOC, TPH and volatile matter (VM) in comparison with the control due to soil contamination by diesel oil. However, there was a significant reduction $(p<0.05)$ in soil $\mathrm{pH}$ and TOC with the introduction of fresh and powdered E. crassipes at different concentrations. Contaminated soil amended with $100 \mathrm{~g}$ of fresh $E$. crassipes showed the highest TOC loss (59.7\%) alongside soil amended with $100 \mathrm{~g}$ of powdered E. crassipes (47.36\%) while the control showed the least TOC loss (0.91\%). Similarly, soil TPH decreased significantly across all concentrations after amendment $(p<0.05)$. Overall, soil amended with fresh $E$. crassipes showed higher TPH loss than soil amended with powdered $E$. crassipes. This study reveals the potentials of using E. crassipes in the remediation of diesel oil contaminated soils. Above all, we demonstrate that fresh E. crassipes is a potentially stronger biostimulant than powdered E. crassipes.
\end{abstract}

Keywords: bioremediation; biostimulant; diesel oil; Eichhornia crassipes, volatile matter

\section{Introduction}

Soil contamination has become a global challenge due to the increasing demand for petroleum-derived substances, causing indiscriminate accidental spillage of petroleum-based substances into the soil. These substances become persistent and harmful when released into the environment which may be during the processing, distribution, and daily use of petroleum and petro-chemical products (Ayotamuno et al., 2006). Soil contaminated with petroleum-derived products, such as diesel oil can pose detrimental effects to the surrounding water table, including the flora and fauna that depend on the soil ecosystem for support (Sztompka, 1999; Ikhajiagbe and Anoliefo, 2012; Osawaru et al., 2013). 
Diesel is a specific liquid fuel used in diesel engines, with ignition that occurs without emitting sparks (Chang, 2000). It is a crude oil-derived product that consists of $75 \%$ saturated hydrocarbons and $25 \%$ aromatic hydrocarbon (Ghaly et al., 2013). Its daily usage encompasses heavy engineering equipment, such as motor vehicles and generators (Ogbo et al., 2009). However, diesel contamination of soil and aquatic ecosystem constitutes a major environmental problem in oil producing nations, especially Nigeria. Diesel has been documented to affect seed germination and plant growth, leading to low agricultural yield and food shortage (Jerome et al., 2016). Diesel contaminated soils could pose potential risks for human habitation and the establishment of agricultural steads due to increased expose and the associated bio-accumulation of harmful hydrocarbon compounds from underground water and agricultural products (Ogbo et al., 2009).

Previous studies have shown the ecological hazard associated with crude oil and several remediation approaches for contaminated soils (Njoku et al., 2012; Ikhajiagbe et al., 2019; Tang and Angela, 2019; Ikhajiagbe and Ogwu, 2020). This includes physical approach that involves the incineration and excavation of contaminated soils (Tang and Angela, 2019), and the chemical approach, which rely on reduction-oxidation and hydrolysis-neutralization reactions to treat contaminated soils (Lim et al., 2014). Nevertheless, both approaches are labor intensive and expensive (Nriagu et al., 2016). Preferably, the biological approach has been used for remediation (sensubioremediation). This process involves the use of living organisms, such as microbes or plants (sensu phytoremediation), which can be efficient and ecologically friendly (Njoku et al., 2012). These organisms are known to transform the physicochemical properties of the soil following several techniques (Adam and Duncan, 2002; Collins, 2009).

Existing bioremediation techniques are natural attenuation, bioaugmentation and biostimulation (Njoku et al., 2012; Sheppard et al., 2019). These techniques rely on the underlying functionality of increasing the soil organic matter contents and decreasing soil $\mathrm{pH}$ for improved outcomes. In some instances, organic matter is added directly to the contaminated soil or indirectly in compost form as a biostimulant (Ogbo et al., 2009). Several plants, such as Peperomia pellucida, Alternanthera brasiliana and Eichhornia crassipes have been investigated for high organic matter content and biostimulation potential for remediation of diesel oil contaminated soils (Ogbo et al., 2009; Sheppard et al., 2019). E. crassipes is used extensively in phytoremediation (Udeh et al., 2013). In a recent study, it was shown to out-perform Peperomia pellucida and Alternanthera brasiliana in a model diesel oil contaminated soil (Ikhajiagbe and Anoliefo, 2012). Despite these studies, there is still a dearth of information on which plant and plant forms show biostimulation efficacy in improving remediation processes of contaminated soils. Therefore, this study was conducted to assess the biostimulation efficacy of fresh and powdered forms of E. crassipes as an effective agent in remediating diesel oil contaminated soils.

\section{Materials and Methods}

Study site

This study was conducted in the botanical garden of the University of Lagos, Nigeria $\left(6.5157^{\circ} \mathrm{N}\right.$, $3.3886^{\circ} \mathrm{E}$ ). Field collection of large quantities of Eichhornia crassipes was conducted along a riverside in the Bariga Local Government Area (LGA) of Lagos State $\left[6.5391^{\circ} \mathrm{N}, 3.3849^{\circ} \mathrm{E}\right]$ by handpicking the plant during the daytime. Using a clean treated gallon, about $40 \mathrm{l}$ of diesel oil was purchased from the Nigeria National Petroleum Cooperation (NNPC) petrol station at Palm Groove in Shomolu LGA, Lagos State. The chemical composition was in line with (Chang, 2000).

\section{Soil preparation and physicochemical analysis}

Using a $10 \mathrm{~m}$ soil auger, $50 \mathrm{~cm}$ of loamy soil samples were obtained directly from the botanical garden. Physicochemical parameters of both the control and diesel contaminated soils were determined prior to usage for amendment following standard procedures of the Association of Official Analytical Chemists (AOAC), 
2005. Soil $\mathrm{pH}$ was measured using a $\mathrm{pH}$ meter (Model PHS-3C). Soil total organic carbon (TOC) and organic matter (OM) were determined following the methods of Nelson and Sommers (1983). Total petroleum hydrocarbon content (TPH) and volatile matter (VM) were assayed as described by Ayotamuno et al. (2006).

\section{Plant preparation}

Freshly harvested E. crassipes stems were shredded in pieces $(3 / 4 \times 20)$ using a standard table knife after washing with clean tap water following Ayotamuno et al. (2006). Next, $5 \mathrm{~kg}$ of the shredded E. crassipes was air-dried, ground into powder, then stored in $5 \mathrm{ml}$ ethanol treated bottles for further experimental use. A similar $5 \mathrm{~kg}$ of the fresh $E$. crassipes was applied directly to the contaminated soil following the method of Swamps (2013).

\section{Soil contamination}

Exactly $21 \mathrm{~kg}$ of loamy soil was air dried, sieved with a standard mesh and then contaminated with 750 $\mathrm{ml} / \mathrm{g} \mathrm{w} / \mathrm{w}$ of diesel oil. Contaminated soils were placed in 9 plastic pots and amended with $50 \mathrm{~g}, 100 \mathrm{~g}$ and 150 $\mathrm{g}$ of fresh and powdered E. crassipes alongside a control $(0 \mathrm{~g})$. The content of each pot was turned twice a week to ensure proper aeration. Soil moisture content was maintained at a $60 \%$ water holding capacity threshold by the monitored addition of distilled water. The set-up was developed in three replicates using a randomized block design and incubation period of 90 days at room temperature $\left( \pm 25^{\circ} \mathrm{C}\right)$. Similar physicochemical analysis as detailed above was conducted on the contaminated soils during and after this period.

\section{Bioremediation analysis}

Bioremediation assessment was done by comparing outputs of the baseline physicochemical analysis before and after diesel soil contamination. Upon the introduction of the fresh and powdered E. crassipes as amendments, soil $\mathrm{pH}$ and TOC were determined at 30,60 and 90 days after contamination (DAC), while TPH was determined at 1, 45 and 90 DAC. Percentage TOC and TPH loss were also quantified and comparatively assessed.

\section{Statistical analysis}

Data were analyzed as mean and standard error following a two-way analysis of variance (ANOVA) IN SPSS $\left(8^{\text {th }}\right.$ edition$)$. The statistical significance of the values obtained was based on a p-value of $(0.05)$.

\section{Results and Discussion}

\section{Baseline physicochemical parameters}

The baseline physicochemical content of the control soil (CSS) and diesel contaminated soil (DCS) measured after contamination indicate that diesel remarkably altered the test soil properties (Table 1). Soil $\mathrm{pH}$ increased significantly in the DCS $(6.49-7.12 ; \mathrm{P}<0.05)$. The high soil $\mathrm{pH}$ was likely caused by the hydrophobic nature of diesel and its potential to induce drought in soil surface layers. This could aggravate salinization and thereby increase $\mathrm{pH}$ values in comparison to the control (Collins, 2009; Njoku et al., 2009). Also, the TOC, TPH and VM significantly increased in diesel contaminated soils $(\mathrm{p}<0.05)$. However, OM significantly decreased $(\mathrm{p}<0.05)$. This was likely caused by a reduction in the exchangeable anion/cation acidity (Ikhajiagbe et al., 2019). Similarly, OM was observed declining in soils with high $\mathrm{pH}$ (7.5) which was associated with reduction in activities and aggregation of beneficial rhizopheric bacteria (David et al., 2019). 
Table 1. Soil physicochemical parameters before bioremediation analysis

\begin{tabular}{|c|c|c|c|c|c|}
\hline Parameters & $\mathrm{pH}$ & TOC (\%) & TPH & VM (\%) & OM (\%) \\
\hline CSS & $6.49 \pm 0.13^{\mathrm{a}}$ & $3.36 \pm 0.12^{\mathrm{a}}$ & ND & $3.90 \pm 0.03^{\mathrm{a}}$ & $5.00 \pm 0.09^{\mathrm{a}}$ \\
\hline DCS & $7.12 \pm 0.08^{\mathrm{b}}$ & $77.92 \pm 0.23^{\mathrm{b}}$ & $49.16 \pm 1.2^{\mathrm{b}}$ & $96.03 \pm 1.2^{\mathrm{b}}$ & $0.10 \pm 0.03^{\mathrm{b}}$ \\
\hline
\end{tabular}

CSS = Control Soil, DCS = Diesel Contaminated Soil, TOC $=$ Total Organic Carbon, TPH $=$ Total Petroleum Hydrocarbon content, $\mathrm{VM}=$ Volatile Matter, $\mathrm{OM}=$ Organic Matter, ND $=$ Not Detected. Alphabet $(\mathrm{a}$ and $\mathrm{b})$ denotes significant difference when parameters for both soil samples were compared.

\section{Effect of diesel contamination on soil pH during bioremediation}

Soil $\mathrm{pH}$ value in DCS was observed to be up to 7.12 and significantly higher than the CSS 6.31 (p < 0.05; Figure 1). However, slight decrease in soil $\mathrm{pH}$ was witnessed in the CSS with increasing DAC. This suggests natural attenuation consistent with the work of Njoku et al. (2009). Furthermore, E. crassipes significantly decreased soil $\mathrm{pH}$ in DCS with increasing DAC $(\mathrm{p}<0.05)$. This is likely due to E. crassipes production of low molecular weight organic acids that lower soil $\mathrm{pH}$ and improve soil fertility through enhanced nitrification and degradation of pollutants (Tang and Angela, 2019). Our result corroborates the work of Ayotamuno et al. (2006) who showed that increased organic matter has lowered the soil $\mathrm{pH}$ in a model crude oil contaminated soil. DCS treated with $100 \mathrm{~g}$ of fresh $E$. crassipes showed the lowest $\mathrm{pH}$ which was nearly equal to that of the CSS. This suggests that fresh E. crassipes is likely a strong biostimulant that can be used to decrease the $\mathrm{pH}$ of contaminated soils, and improve soil properties.

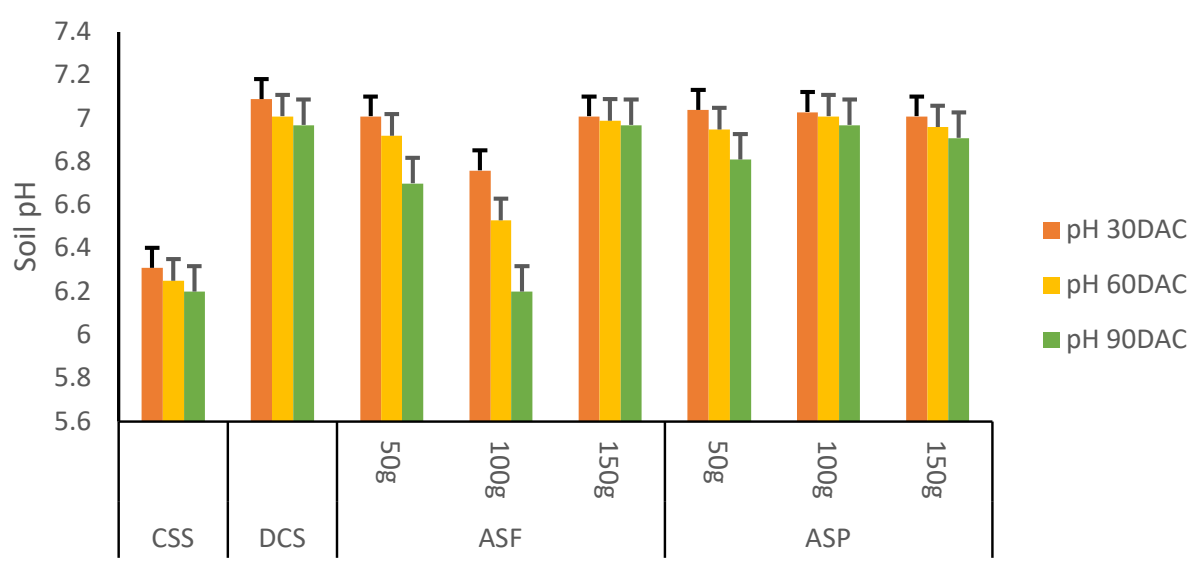

Figure 1. Change in soil $\mathrm{pH}$ levels in diesel contaminated soil during bioremediation analysis Values are means with standard errors. CSS $=$ Control Soil, DCS $=$ Diesel Contaminated Soil, ASF = Amended Soil with Fresh E. crassipes, ASP = Amended Soil with Powdered E. crassipes, DAC= Days After Contamination.

\section{Effect of diesel contamination on total organic carbon (TOC) during bioremediation}

TOC concentration was significantly higher in the DCS than the CSS $(\mathrm{p}<0.05$; Figure 2). After amendment with E. crassipes, TOC significantly decreased with increasing DAC. Fresh $100 \mathrm{~g}$ of E. crassipes at 90 DAC had the least TOC (24.12), which was significantly higher than the CSS at 90 DASC. Comparison of both fresh and powdered E. crassipes on TOC showed a significant decrease in concentration for the soils amended with fresh $E$. crassipes above that of the powdered form across all DAC. TOC has been observed to be higher in soils amended with fresh organic matter compared to the processed form (Waleed et al., 2020). However, soil contaminated by derived hydrocarbon substances could lead to high TOC of soils. This result is consistent with the work of Devatha et al. (2019) who reported that diesel contamination significantly increased TOC levels due to increase in TPH. Also, Musa et al. (2018) suggested that reduction in soil TOC may signify biodegradation of soil hydrocarbons. 


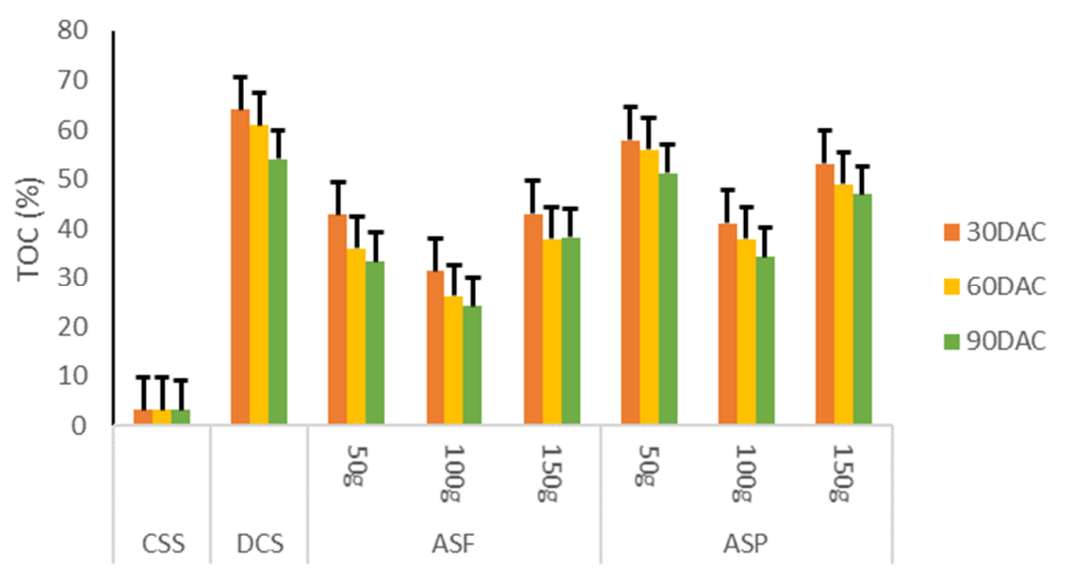

Figure 2. Change in soil TOC levels in diesel contaminated soil during bioremediation analysis Values are means with standard errors. CSS $=$ Control Soil, DCS $=$ Diesel Contaminated Soil, TOC $=$ Total Organic Carbon, ASF = Amended Soil with Fresh E. crassipes, ASP = Amended Soil with Powdered E. crassipes, DAC $=$ Days After Contamination.

Percentage TOC loss was significantly different $(\mathrm{p}<0.05)$ across all analyzed soils for different amendment concentration (Figure 3). Contaminated soil amended with $100 \mathrm{~g}$ of fresh E. crassipes at $30 \mathrm{DAC}$ showed the highest TOC loss (59.7\%). After this was, the contaminated soil amended with $100 \mathrm{~g}$ of powdered E. crassipes $(47.36 \%)$, while the CSS at 60 DAC showed the least TOC $(0.91 \%)$. This suggests that fresh $E$. crassipes exerts a greater biostimulation effect in TOC in diesel contaminated soils than both the powdered $E$. crassipes and the process of natural attenuation.
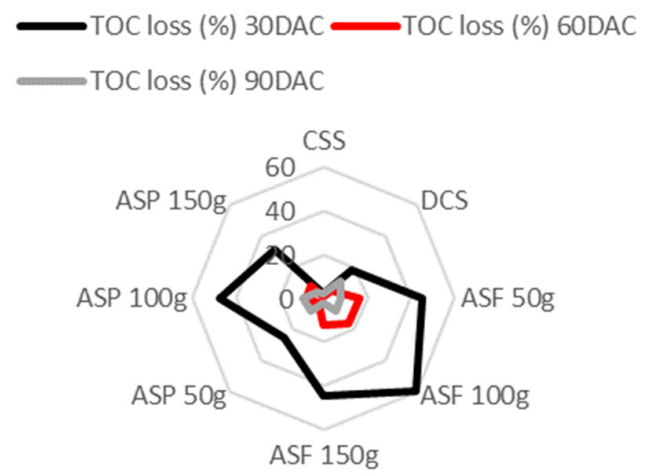

Figure 3. Percentage loss in total organic carbon (\% TOC) of E. crassipes amended diesel contaminated soil

CSS $=$ Control Soil, DCS $=$ Diesel oil Contaminated Soil, ASF $=$ Amended Soil with Fresh E. crassipes, ASP $=$ Amended Soil with Powdered E. crassipes, DAC $=$ Days After Contamination.

\section{Effect of diesel contamination on total petroleum hydrocarbon (TPH) during bioremediation}

TPH concentration in the DCS for the three assayed DACs was significantly higher than the CSS ( $p$ $<0.05$ ), However, TPH was not detected in the CSS at 10, 45 and 90 DAC (Figure 4). TPH concentration slightly reduced with increasing DAC. This phenomenon may be due to natural attenuation. Upon soil amendment with $E$. crassipes, TPH significantly decreased with increasing DAC across all treatments. TPH was lowest in soil treated with $100 \mathrm{~g}$ of fresh E. crassipes at $90 \mathrm{DAC}$ (9.09), whereas it was highest in DSC at 1 DAC (49.02). This result indicates that the use of $E$. crassipes in the treatment of diesel contaminated soils can aid in TPH reduction. Furthermore, TPH significantly decreased in soils treated with fresh $E$. crassipes than 
in soils treated with powdered E. crassipes across all DACs. This is likely due to the active living matter in the fresh $E$. crassipes which is a direct contrast to the powdered $E$. crassipes. This result is consistent with the work of Udeh et al. (2013) who reported that fresh E. crassipes is an effective biostimulant in the treatment of hydrocarbon polluted soils.

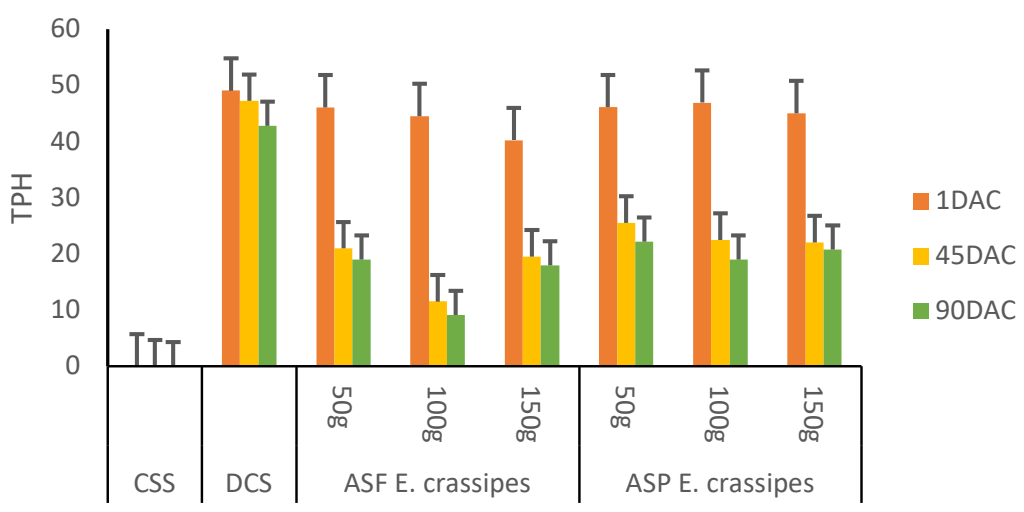

Figure 4. Change in soil TPH levels in diesel contaminated soil during bioremediation analysis Values are means with standard errors. CSS $=$ Control Soil, DCS $=$ Diesel oil Contaminated Soil, TPH $=$ Total Petroleum Hydrocarbon, ASF = Amended Soil with Fresh E. crassipes, ASP = Amended Soil with Powdered E. crassipes, DAC $=$ Days After Contamination.

TPH significantly decreased at 1, 45 and 90 DAC ( $p<0.05$; Figure 5$)$. Contaminated soils amended with $100 \mathrm{~g}$ of fresh E. crassipes had the highest TPH loss (72.24\%). Following this were contaminated soils amended with $50 \mathrm{~g}$ of fresh E. crassipes (54.45\%). Compared with other treatments, diesel contaminated soil with no treatment showed the least TPH loss (3.71\%). Although soil TPH can be reduced by natural attenuation, it takes a longer time comparison with the use of organic matter as stimulants. This result corroborates the findings of Akpe et al. (2015), who demonstrated high TPH loss in hydrocarbon polluted soils within 56 days after biostimulation with plantain peels and guinea corn shaft. TPH was not detected in the CSS. Also, within the amendment types, percentage TPH loss with the fresh E. crassipes was significantly higher than in the powdered E. crassipes. This is likely due to high utilization of organic carbon in fresh $E$. crassipes. This is also similar to the study of Swamps (2013), who used powdered $E$. crassipes to assess bioremediation in petroleum polluted mangrove swamps in the Niger Delta and observed high TPH loss of up to $75.36 \%$ after 70 days. They suggested that the high TPH loss recorded was due to the presence of nutrients from organic wastes.

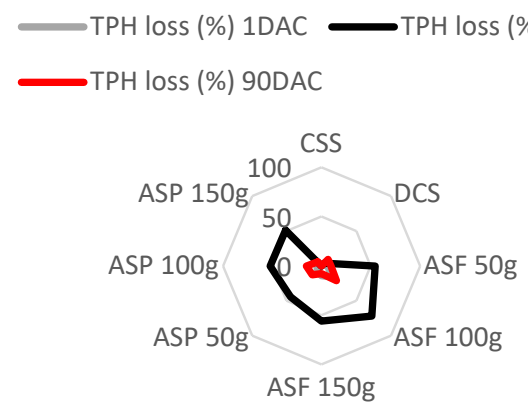

Figure 5. Percentage total petroleum hydrocarbon (\% TPH) loss in the E. crassipes amended diesel contaminated soil CSS $=$ Control Soil, DCS $=$ Diesel Contaminated Soil, ASF $=$ Amended Soil with Fresh E. crassipes, ASP $=$ Amended Soil with Powdered E. crassipes, DAC= Days After Contamination. 


\section{Conclusions}

This research has demonstrated that fresh E. crassipes is likely a more potent biostimulant in the remediation of soils contaminated with petroleum diesel than its powdered variant. This was buttressed by the significant decrease in soil $\mathrm{pH}$, soil total organic carbon (TOC) and total petroleum hydrocarbon (TPH), in concert with high TOC and TPH loss. Because of the timeframe of this study and limitations with the microbial assessment of fresh organic matter, further work is required to isolate the microbes that aid fresh $E$. crassipes in biodegradation for improved remediation strategies.

\section{Authors' Contributions}

OFM and CCN designed and conducted the study, including the initial writing and editing of the manuscript. OFM wrote the first draft of the manuscript. MSI conducted the statistical analysis and wrote the final draft of the manuscript.

All authors read and approved the final manuscript.

\section{Acknowledgements}

We are grateful for the assistance received from some staff members of the Environmental Biology unit of the Department of Cell Biology and Genetics, University of Lagos, Nigeria. The advice provided by Dr. K.L. Njoku at the start of this study is very much appreciated.

\section{Conflict of Interests}

The authors declare that there are no conflicts of interest related to this article.

\section{References}

Adam G, Duncan H (2002). Influence of diesel fuel on seed germination. Environmental Pollution 120 (2):363-370. https://doi.org/10.1016/s0269-7491(02)00119-7

Akpe AR, Esumeh FI, Aigere SP, Umanu G, Obiazi H (2015). Efficiency of plantain peels and guinea corn shaft for bioremediation of crude oil polluted soil. Journal of Microbiology Research 5:31-40. https://doi.org/10.5923/j.microbiology.20150501.04

AOAC (2005). Association of Official Analytical Chemists. Official methods of analysis of AOAC international (18 ${ }^{\text {th }}$ ed). AOAC International, Rockville, MD.

Ayotamuno JM, Kogbara RB, Egwuenum PN (2006). Comparison of corn and elephant grass in the phytoremediation of a petroleum hydrocarbon contaminated agricultural soil in Port Harcourt, Nigeria. Journal of Food Agriculture and Environment 4:218-222.

Chang S (2000). Diesel fuel analysis. Exxon Research and Engineering Co., Annandale, NJ, USA.

Collins CD (2009). Implementing phytoremediation of petroleum hydrocarbons. In: Methods in Biotechnology. Phytoremediation: Methods and Reviews 23:99-108. https://doi.org/10.1007/978-1-59745-098-0_8

Devatha CP, Vishal AV, Rao JPC (2019). Investigation of physical and chemical characteristics on soil due to crude oil contamination and its remediation. Applied Water Science 9(4):89.

https://doi.org/10.1007/s13201-019-0970-4

Ghaly AE, Yusran A, Dave D (2013). Effects of biostimulation and bioaugmentation on the degradation of pyrene in soil. Journal of Bioremediation and Biodegradation 5:1-13. https://doi.org/10.4172/2155-6199.S7-005 
Ikhajiagbe B, Anoliefo GO (2012). Substrate bioaugumentation of waste engine oil polluted soil. Research Journal of Environmental and Earth Sciences 4(1):60-67.

Ikhajiagbe B, Ogwu MC (2020). Hazard quotient, microbial diversity and plant composition of spent crude oil pollutedsoil. Beni-Suef University Journal of Basic and Applied Sciences 9(1):1-9. https://doi.org/10.1186/s43088-020-00052-0

Ikhajiagbe B, Saheed MI, Okeme OJ (2019). Effect of changes in soil cation exchange capacity on the reclamation of lead by Eleusine indica (L.) Gaertn. FUDMA Journal of Sciences 3(4):176 -183.

Kabelka D, Kincl D, Janeček M, Vopravil J, Vráblík P (2019). Reduction in soil organic matter loss caused by water erosion in inter-rows of hop gardens. Soil and Water Research 14(3):172-182. https://doi.org/10.17221/135/2018-SWR

Lim K, Shukor M, Wasoh H (2014). Physical, chemical, and biological methods for removal of arsenic compounds. BioMed Research International. http://dx.doi.org/10.1155/2014/503784

Musa SI, Foluke A, Njoku KL, Ndiribe CC (2018). The effect of bioremediated diesel polluted soil amended with Eicchornia crassipes (water hyacinth) on the germination parameters of Amaranthus hybridus L. (green amaranth). International Journal of Science and Research 7(1):1686-1688. https://doi.org/10.21275/ART20179643

Nelson DW, Sommers LE (1983). Total carbon, organic carbon and organic matter. Methods of soil analysis part II. ASA/SSSA, Madison WI. pp 579.

Njoku K, Akinola M, Oboh B (2009). Phytoremediation of crude oil contaminated soil: The effect of growth of Glycine max on physico-chemistry and crude oil contents of soil. Nature and Science 7(10):79-87.

Njoku K, Akinola M, Oboh B (2012). Phytoremediation of crude oil polluted soil: Effect of cow dung augmentation on the remediation of crude oil polluted soil by Glycine max. Journal of Applied Sciences Research 8:277-282. https://ir.unilag.edu.ng/handle/123456789/5249

Nriagu J, Udofia E, Ekong I, Ebuk G (2016). Health risks associated with oil pollution in the Niger Delta, Nigeria. International Journal of Environmental Research and Public Health 13:364. https://doi.org/10.3390/ijerph13030346

Ogbo E, Zibigha M, Odogu G (2009). The effect of crude oil on growth of the weed (Paspalum scrobiculatum L.) phytoremediation potential of the plant. African Journal of Environmental Science and Technology 3:229-233.

Osawaru ME, Ogwu MC, Braimah L (2013). Growth responses of two cultivated okra species (Abelmoschus caillei (A. Chev.) Stevels. and Abelmoschus esculentus (Linn.) Moench.) In crude oil contaminated soil. Nigerian Journal of Basic and Applied Sciences 21(3):215-226. https://doi.org/10.4314/njbas.v21i3.7

Sheppard PJ, Adetutu EM, Makadia TH, Ball AS (2019). Microbial community and ecotoxicity analysis of bioremediated, weathered hydrocarbon-contaminated soil. Soil Research 49:261-269. https://doi.org/10.1071/SR10159

Swamps HPM (2013). Bioremediation of petroleum hydrocarbon polluted mangrove swamps using nutrient formula produced from water hyacinth (Eicchornia crassipes). American Journal of Environmental Science 9:343-366. https://doi.org/10.3844/AJESSP.2013.348.366

Sztompka E (1999). Biodegradation of engine oil in soil. Acta Microbiologica Polonica 48:185-196.

Tang KHD, Angela J (2019). Phytoremediation of crude oil-contaminated soil with local plant species. In: IOP Conference Series: Materials Science and Engineering 495(1):012054. https://doi.org/10.1088/1757$899 X / 495 / 1 / 012054$

Udeh NU, Nwaogazie IL, Momoh Y (2013). Bioremediation of a crude oil contaminated soil using water hyacinth (Eichhornia crassipes). Advances in Applied Science Research 4:362-369.

Waleed A, Mumtaz K, Rhonda J, Mohammed A, Rashid A (2020). Efficacy of soil amendments in organic farming systems. Agrociencia 54(1):2-30. 
OPEN ACCESS

(c) (2)

The journal offers free, immediate, and unrestricted access to peer-reviewed research and scholarly work. Users are allowed to read, download, copy, distribute, print, search, or link to the full texts of the articles, or use them for any other lawful purpose, without asking prior permission from the publisher or the author.

License - Articles published in Notulae Scientia Biologicae are Open-Access, distributed under the terms and conditions of the Creative Commons Attribution (CC BY 4.0) License.

(C) Articles by the authors; SHST, Cluj-Napoca, Romania. The journal allows the author(s) to hold the copyright/to retain publishing rights without restriction. 